SIR-It would take too long to take up every piece of explicit and implicit racism in the article on the boycott of South Africa (Nature 327, 259; 1987). Instead I would like to outline some arguments for the scientific boycott of South Africa.

First, far from being a "scandal", there is a perfectly good moral case for excluding South Africans; those whites who choose to enjoy the advantages of living comfortably in South Africa, at the expense of the black population, are party to denying the vast majority of the South African population "the right to contribute to research", purely on grounds of race. It is, therefore, only right that they should be denied the benefits of attendance at international conferences and so on. No doubt some white South African scientists are secretly working for the overthrow of the present system, but no doubt they would equally secretly welcome the boycott that seeks to hasten that overthrow.

Apartheid is conveniently taken to be the whole issue, but it is not. It is only one form of white domination, which did not begin all of a sudden in 1950. John Maddox's "reformers" are those who think it might no longer be the best way of keeping the mass of the black population in subjugation. White rule in South Africa is a system of colonial settler domination, established and maintained by force. Typically, Maddox refers to "bombings" by the African National Congress, but is silent about the South African state's continual acts of aggression against its neighbours and against the mass of its own people. White South Africa is making war on the black population. That is what "reformer" Professor Cloete's right of South Africa to defend itself means. In response, the people of South Africa are beginning their war of liberation; which brings me to the more important case for a scientific boycott - to weaken the power of the white South African state to wage war against the people.

Most readers of Nature would agree that scientists are rather valuable to a country, more so perhaps than singers or rugby players. It is unnecessary to argue the case that science is essential to the production of weapons, to the supporting industries and to the economy that sustains a war effort. The article itself makes it abundantly clear that science in South Africa is utterly dependent on the international scientific community. Maddox is effusive in his praises of (white) South African science, but if South Africa were totally cut off, world science would hardly notice, while South African science would be, as one of Maddox's informants puts it, "dead". This process of isolation would also weaken the regime by encouraging native white South African scientists (and other intelligent people) to leave the country for the duration.

I presume Maddox is one of those who favour 'peaceful change' in South Africa, by which they mean that the white rulers should come up with some less offensive system without being subject to any serious coercion. In fact, the only chance of a more-or-less peaceful solution is for the white supremacists to realize that they must lose, and accordingly negotiate a surrender of power. That is why all humane scientists should support measures such as the scientific boycott which contribute to so weakening South Africa that even those dinosaurs recognize their day is done.

The profound racism of Maddox's approach is evident from his outrage at any restriction on the right of 6 million white South Aricans to take part in scientific research, together with his complete indifference to the fact (evident even from his article) that 17 million black South Aricans are denied the possibility of a scientific education and career. We are often told that the issue of South Africa raises complicated and difficult questions. In fact, in essence there is only one question - which side are you on? The side of the racists, seeking to maintain their domination by military force, or the side of the people, seeking to establish a nonracial democracy? I very much hope that on this issue Nature is not the voice of British science.

8 Agincourt Road,

London NW3 $2 P D, U K$

\section{University sports}

SIR-I hope that British universities will learn from the experience of their transatlantic counterparts (Nature 325, 470; 1987) the lesson that they are likely to get badly burned if they attempt to introduce professional or quasiprofessional athleticism on the US model.

There seem to me to be only two sensible ways of handling intercollegiate athletics, and, in general, US universities adopt an unsatisfactory mixture of the two that gives them the worst of both worlds.

One method is to call things by their right names and employ a professional football or basketball team, whose members are paid high salaries but are in no sense students at the university. In a few years, they should obviously be able to earn enough to put themselves through college if they could meet regular academic requirements.

The other method is to admit all students for whom there are places and who meet the academic requirements of the university, and then choose teams from them. This is approximately the system that I assume still exists in British universities.

The unfortunate aspect of the present system of recruitment for intercollegiate athletics in the United States is the double educational standard that it implies. For example, if students in general require a Scholastic Aptitude Test (SAT) score of, say, 1,100 for entry to a university, athletes will probably be admitted with SAT scores of 700 to 800 . In addition, the temptation for enthusiastic alumni to 'sweeten the pot' (illegally, of course) by paying for cars and apartments for athletes in order to induce them to come to the alma mater appear to be quite irresistible.

This leads to the kind of unpleasantness that has recently been seen at Southern Methodist University in Texas, which has effectively been banned from intercollegiate athletics for one year for illegal payments to players or the earlier stupidity at the University of Georgia where a faculty member was fired for failing athletes academically, and had to sue the university to get reinstated. She won, and the president of the university resigned.

In short, I urge you to use your influence to prevent British universities from starting down the slippery slope of giving some students easier academic options in the hope of getting a better football team or a faster boat crew. Universities in the United Kingdom have been treated in a stupid and niggardly fashion by the government but there is no need for them to compound their problems by getting drawn into the mess of semiprofessional athletics. It will raise almost no money for educational purposes, and they will get involved in a nasty mixture of half-truths and evasions about who is or is not a student eligible to play for the university.

Let them keep out of it altogether and concentrate their energies and resources on higher education.

Cecil S. Cummins

Department of Anaerobic Microbiology,

Virginia Polytechnic Institute

and State University,

Blacksburg, Virginia 24061, USA

\section{Bad example}

SIR-What hope have we of getting the facts through to the general public when Nature gets it wrong ("Keeping politics out of AIDS" Nature 327, 447; 1987)? You talk about the spread of AIDS and infection with AIDS; it is the virus (HIV) which is infectious, not the syndrome. Maybe I am being pedantic, but despite extensive education campaigns there is still considerable confusion over the facts about AIDS. Please don't add to it.

Ruth H. WALKer

Scottish AIDS Monitor,

PO Box 169 ,

Edinburgh, $U K$ 